\title{
THE SILENCING OF QUEER VOICES IN THE LITIGATION OVER TRINITY WESTERN UNIVERSITY'S PROPOSED LAW SCHOOL
}

\author{
Pippa Feinstein \\ Sarah E. Hamill*
}

This article assesses to what extent the recent litigation over the accreditation of Trinity Western University's proposed law school includes and considers queer voices. We argue that a close examination of how queer people's voices appear in these decisions reveals that when queer voices are absent or marginal, queer people's rights are mischaracterized. In turn the mischaracterization and misunderstanding which flows from the failure to properly include queer voices hinders the ongoing struggle for queer equality. We rely on discourse analysis to make our argument. We argue that Canadian courts should seek to ground their decisions relating to queer equality in the lived experiences of queer people. Here we argue that Justice L'Heureux-Dube's dissent in Trinity Western University $v$ British Columbia College of Teachers offers a good blueprint for future decisions to follow as they engage with queer equality.

Dans cet article, l'auteure s'interroge sur la mesure dans laquelle le récent litige au sujet de l'agrément de la faculté de droit proposée par l'université Trinity Western tient compte des opinions des personnes queers. Elle soutient qu'un examen attentif de la façon dont les opinions des queers sont présentées dans ces décisions montre que, lorsque les voix de ces personnes ne sont pas exprimées ou le sont de façon marginale, les droits de celles-ci sont mal interprétés. Or, cette interprétation et cette compréhension erronées, qui découlent d'une présentation inadéquate des opinions des personnes queers, nuisent à la lutte pour l'égalité que ces personnes doivent constamment mener. C'est du moins ce que montre une analyse du discours. De l'avis de l'auteure, les tribunaux canadiens devraient s'efforcer de fonder leurs décisions concernant les droits à l'égalité des personnes queers sur les expériences vécues par celles-ci. À cet égard, elle estime que le jugement dissident qu'a rendu la juge L'Heureux-Dubé dans l'arrêt Université Trinity Western c. British Columbia College of Teachers constitue un modèle inspirant en vue des prochaines décisions que les tribunaux seront appelés à rendre au sujet des droits à l'égalité des personnes queers.

Recent years have seen several advances in queer ${ }^{1}$ people's struggle for equality. ${ }^{2}$ However, for most of Canada's history, its courts have enforced domestic laws that marginalized and criminalized the queer

* Pippa Feinstein is a sole practitioner based in Toronto and Sarah E. Hamill is an Assistant Professor at the School of Law, Trinity College Dublin. The authors would like to thank two anonymous peer reviewers for helpful comments.

1 Use of the term "queer" is politically-informed and seeks to reclaim a term that had historically been used to disparage the LGBTQQ2SIA* community. LGBTQQ2SIA* stands for Lesbian, Gay, Bisexual, Trans-identified, Queer, Questioning, Two-Spirited, Intersex, and Asexual with the * representing the inclusion of other identities not specifically indicated in the acronym. We use the term 'queer' as an umbrella term in this article.

2 Egan v Canada, [1995] 2 SCR 513. Also, note that 1995 saw the first openly gay judge, Harvey Brownstone, appointed, while 2016 saw the appointment of Canada's first transgender judge, Kael McKenzie. Same-sex marriage was introduced by Civil Marriage Act, SC 2005, c 33. 
community. ${ }^{3}$ While there are ongoing attempts to redress this historic discrimination, such as formal pardons for those whose lives were destroyed by homophobic criminal laws, this work has only just begun, ${ }^{4}$ and the legal system as a whole still has a long way to go in ensuring the safety and equality of queer people.

At the same time, Canadian law schools and law societies are increasingly recognizing that a diverse legal profession that is representative of minorities will better fulfil the obligations of the profession to ensure justice for those minorities. ${ }^{5}$ Canadian courts have begun a similar process, affirming the need to promote greater diversity amongst those on the bench as a necessary part of any effort to ensure justice for the diverse Canadian population. ${ }^{6}$ Implicit in these developments is an understanding of the judicial system as a fundamentally human system in which the lived experiences of legal practitioners and members of the judiciary inform the way in which justice is realized in any given case.

Recent litigation over Trinity Western University's [TWU] proposed law school and the impacts of its accreditation on the queer community highlight areas of continuing tension between the judicial system and marginalized groups. This article seeks to highlight some successes and shortcomings of the past TWU decisions in the hope that it can provide some 'lessons learned' to help inform future litigation and an ultimate decision in this matter before the Supreme Court of Canada.

The litigation examined in this article arose when three provincial law societies - the Nova Scotia Barristers' Society [NSBS], the Law Society of Upper Canada [LSUC], and the Law Society of British Columbia [LSBC] - refused to accredit TWU's proposed law degree. Each rooted their objection in TWU's Community Covenant which requires students "to embody attitudes and to practice actions identified in the Bible as virtues, and to avoid those portrayed as destructive" including avoiding "sexual

3 Egale, “The Just Society Report: Grossly Indecent: Confronting the Legacy of State Sponsored Discrimination Against Canada's LGBTQ2SI Communities", online:

$<$ https://egale.ca/wpcontent/uploads/2016/06/FINAL_REPORT_EGALE.pdf $>$. Lingering discriminatory sodomy provisions in the Criminal Code were only repealed in 2016, see: Canada, Department of Justice, "Bill C-32: An Act related to the repeal of section 159 of the Criminal Code, December 15, 2016, online: $<\mathrm{http} / /$ www.justice.gc.ca/eng/csjsjc/pl/charter-charte/cs_s159-ec_s159.html>.

4 See e.g. John Ibbitson, "Liberals' gay-pardon decision applauded but obstacles still exist" Globe and Mail (28 February 2016) online: http://www.theglobeandmail.com/news/politics/liberals-gay-pardon-decision-applauded-but-obstacles-stillexist/article28944769/; Gary Kinsman \& Patrizia Gentile, The Canadian War on Queers: National Security as Sexual Regulation (Vancouver: UBC Press, 2010).

5 See e.g. M Cooper, J Brockman \& I Hoffart, "Final Report on Equity and Diversity in Alberta's Legal Profession", Report prepared for The Law Society of Alberta, 2004; The Law Society of British Columbia, "Towards a More Representative Legal Profession: Better practices, better workplaces, better results", June 2012; and FM Kay, C Masuch, \& P Curry, "Diversity and Change: The Contemporary Legal Profession in Ontario, A Report to The Law Society of Upper Canada", September 2004. Given the ongoing TWU litigation, it is important to note that these reports discuss how unconscious biases and systemic barriers to professional success within the legal profession already adversely affect the careers of lawyers belonging to various minority groups. For example, the Alberta report conducted an extensive survey of lawyers in the province and found that $88 \%$ of queer lawyers reported discrimination in their workplaces due to their sexual orientation and $40 \%$ of queer lawyers reported personal experiences of discrimination when seeking employment with law firms. See also: Jena McGill \& Amy Salyzyn, "Queer Insights on Women in the Legal Profession" (2014) 17:2 Legal Ethics 231; Faisal Bhabha, "Towards a Pedagogy of Diversity in Legal Education” (2014), Osgoode Legal Studies Research Paper Series, 1.

6 See e.g. Samreen Beg \& Lorne Sossin, “Diversity, Transparency \& Inclusion in Canada's Judiciary”, in Debating Judicial Appointments in an Age of Diversity, Graham Gee \& Erika Rackley, eds, (London: Routledge 2017); Sherri Borden Colley, “'It's a very white bench': Judges to mentor black and Indigenous lawyers", CBC News (August 02, 2017) online: $<$ http://www.cbc.ca/news/canada/nova-scotia/african-nova-scotian-blacks-indigenous-judges-diversity$1.4230905>$. 
intimacy that violates the sacredness of marriage between a man and a woman." In response to the three societies' refusal to accredit, TWU launched court cases against each of these law societies. ${ }^{8}$ The decisions in all three cases have subsequently been appealed. ${ }^{9}$

These cases are not the first time TWU has challenged the non-accreditation of one of its degrees. In 2001, the university successfully challenged the British Columbia College of Teachers' [BCCT] refusal to accredit its teacher training program. ${ }^{10}$ At issue in the 2001 case, much as with the recent cases, was TWU's Community Covenant and its prohibition of homosexual behaviour. Admittedly, there is more to the Covenant than its comments about marriage and sexual behaviour and the exact wording has changed slightly since $B C C T .{ }^{11}$ Nonetheless, the Covenant's prohibition on certain kinds of sexual behaviour remains the source of the objection to TWU's proposed law school because of its effects on members of the queer community. ${ }^{12}$

As a result, there are seven court decisions (not counting the lower court decisions in $B C C T$ ) to date concerning the TWU's Covenant, providing ample material in which to identify certain judicial patterns and tendencies. TWU litigation to date has involved a complex exercise in trying to balance and integrate religious freedom and equality rights, both constitutionally enshrined and both, at times, fundamentally incompatible with each other. While some Canadian courts and legal academics are doing the necessary and difficult work to tease out these issues and better build a vision for Canadian inclusivity, there has been a tendency in the majority of TWU decisions to silence queer voices and the lived experiences of discrimination amongst members of the queer community. This silence extends to the real impacts of these TWU decisions on queer people's equality, their visibility and inclusion in Canadian society, and the extent to which these court decisions provide any redress for historic and continuing homophobia and transphobia. ${ }^{13}$

In this article, we examine the extent to which the decisions rendered in each case included and considered queer voices, and assess how this informed the way in which the relationship between religious and equality rights in each TWU case was addressed. ${ }^{14}$ This dual focus is necessary because we believe

7 Trinity Western University, "Community Covenant Agreement" online:

$<$ https://www8.twu.ca/studenthandbook/university-policies/community-covenant-agreement.html > at 2-3.

8 Trinity Western University v Nova Scotia Barristers' Society 2015 NSSC 25 [NSBS]; Trinity Western University v The

Law Society of Upper Canada, 2015 ONSC 4250 [LSUC]; Trinity Western University $v$ The Law Society of British Columbia, 2015 BCSC 2326 [LSBC].

9 Trinity Western University $v$ The Law Society of British Columbia, 2016 BCCA 423 [LSBC Appeal], leave to appeal to SCC granted, 2017 CanLII 8574; Trinity Western University $v$ The Law Society of Upper Canada, 2016 ONCA [LSUC Appeal] leave to appeal to SCC granted, 2017 CanLII 8575; The Nova Scotia Barrister's Society v Trinity Western University, 2016 NSCA 59 [NSBS Appeal].

10 Trinity Western University v British Columbia College of Teachers, 2001 SCC 31, [2001] 1 SCR 772 [BCCT]

11 Ibid at 794-99. The then "Community Standards Agreement" required students to: "Refrain from practices that are biblically condemned. These include but are not limited to drunkenness (Eph. 5:18), swearing or use of profane language (Eph. 4:29, 5:4; Jas 3:1-12) ... abortion (Ex. 20:13; Ps. 139:13-16 ... and sexual sins including premarital sex, adultery, homosexual behaviour, and viewing of pornography (I Cor. 6:12-20; Eph. 4:17-24; I Thess. 4:3-8; Rom. 2:26-27; I Tim. 1:9-10). Furthermore married members of the community agree to maintain the sanctity of marriage and to take every positive step possible to avoid divorce."

12 It is important to note that litigation in $\mathrm{BC}$ also addressed impacts of other terms in the Covenant on women's equality rights.

13 For example, see the decision of the LSBC Appeal, supra note 9 at para 170 (framing the harm as "den[ying] the validity of same-sex marriage"). This is an issue we will discuss further in this article.

14 For some discussion of the legal arguments see e.g. Howard Kislowicz, "Developments in Religious Freedom: What Saguenay and Loyola Tell Us and Don't - About the Trinity Western Law School Case" (2016) 72 SCLR (2d) 75. See also, Jena McGill, ““'Now it’s My Rights Versus Yours': Equality in Tension with Religious Freedoms” (2016) 53:3 Alta L Rev 583. 
the extent to which judicial decisions affirm and defend the equality of queer people's rights is determined by the extent to which they understand and express those rights as articulated by queer people. TWU litigation to date has shown that when queer voices do not figure prominently in the litigation process (via interveners and expert witnesses), and queer voices do not figure prominently in the written decisions (to illustrate judges' consideration of them), it affects the litigation outcome: queer people's rights tend to be mischaracterized, their experiences misunderstood, and their ongoing struggle for equality stunted. ${ }^{15}$

We rely largely on discourse analysis to inform our approach, recognizing "[1]anguage as a social practice, determined by social structures" 16 and that language can also determine social structures. ${ }^{17}$ Our use of discourse analysis is not unprecedented, legal scholars and sociologists have been exploring the value of discourse analysis in examining legal decisions for a number of years already. ${ }^{18}$ Studying the language used in legal documents and decisions can reveal certain social undercurrents that inform ways in which law develops. For example, Johanna Niemi-Kiesilainen, Paivi Honkatukia's and Minna Ruuskanen's study examined Finnish case law dealing with violence against women to illustrate how hidden assumptions concerning sex and gender held by legal practitioners and the judiciary tended to silence women's voices in these cases and contribute to the unresponsiveness of the judicial system to gendered violence. ${ }^{19}$ Further, more traditional rules for legal interpretation of case law focus intensely on the text and specific language used in court decisions - all words and their potential meanings are pored over, as are the potential meanings of any identified omissions. As such, specifically textual analyses of past decisions are a crucial way in which Canadian legal precedent is established.

Discourse analysis is especially suited to analyzing how judicial decisions have silenced queer voices in TWU litigation to date. The ways in which queer people and their advocates appear in these decisions, or do not appear, can significantly impact the way Canadian case law develops vis-a-vis queer people and their equality. For example, in the trial-level decision of $L S B C v T W U,{ }^{20}$ queer people and their rights were hardly mentioned and interveners representing queer people were excluded from presenting oral arguments before the court entirely. Ultimately, the decision in that case precluded the LSBC from ensuring that queer people would have equal access to law school places and by extension the legal profession, in essence preventing the law society from fulfilling part of its mandate to ensure greater representation and diversity within the profession. However, at no point does the court recognize this realworld consequence for queer people: queer people were invisible in the litigation process, and the outcome reinforced their invisibility. Similarly, in the trial-level decision of $N S B S \vee T W U^{21}$ and the appeal-level decision of $L S B C \vee T W U, 22$ the courts mischaracterized and subsequently dismissed queer people's equality rights, incorrectly focusing on issues related to marriage equality rather than persistent homophobia in Canada. Again the results of those cases not only set back queer people's struggle for equality by effectively denying them equal access to law school and representation in the legal profession,

15 Again, we explore this in more depth below.

16 N Fairclough, Language and Power (Longmans, 1989) referenced in Rosemary Huisman, "The Relevance of Discourse Analysis to Legal Practice" (1991) 7 Austl JL \&Soc'y 27 at 27.

17 Huisman, supra, note 16 at 27.

18 Ibid. See also: Roger W Shuy, "Discourse Analysis in the Legal Context" in Deborah Schiffrin, Deborah Tannen \& Heidi E Hamilton, eds, The Handbook of Discourse Analysis, (Oxford: Blackwell, 2001) at 437. For an example of this kind of analysis see, Emma Cunliffe, Murder, Medicime, and Motherhood (Oxford: Hart Publishing, 2011).

19 Johanna Niemi-Kiesilainen, Paivi Honkatukia \& Minna Ruuskanen, "Legal Texts as Discourses" in Asa Svensson, EvaMarie Gunnarsson \& Maragaret Davies, eds, Exploiting the Limits of Law (Abingdon; Ashgate, 2007) 69.

20 Supra note 9. We will discuss this more in the third part of this article.

21 Ibid. Again, we will discuss this more in the third part of this article.

22 Ibid. We will discuss this more in the third part of this article. 
they also perpetuate and institutionalize the misunderstanding and marginalization of queer people within Canadian jurisprudence. ${ }^{23}$

It is also important to note that our approach supports a fulsome Charter equality ("section 15") analysis: according to established case law, courts must consider the way in which the actual discrimination is experienced by the section 15 claimant. ${ }^{24}$ Courts are required to seek to understand and make visible the lived experiences of queer people alleging discrimination in order to properly characterize and consider their equality rights. Without such an understanding, future decisions will silence queer voices and the courts will be unable to undertake a full, rigorous section 15 analysis, meaning that any balancing of engaged Charter rights in these cases will be incomplete.

This article is organized into three parts. First, we begin with a brief overview of queer theory and queer legal theory, sharing practical roadmaps provided by leading queer legal theorist Francisco Valdes and queer activist Beth Barrett ${ }^{25}$ for how queer theory can be relied on to improve outcomes in queer equality cases. This section also offers a brief discussion of some of the earlier Canadian jurisprudence around queer equality and religious freedom. Part two of this article discusses Justice L'Heureux-Dubé's dissent in $B C C T$ which exemplifies how to ground decisions in the lived experiences of queer people and how to ensure minorities remain visible and understood in decisions that will impact their equality. As such, we argue that her decision should form a template or blueprint for further judicial decisions concerning TWU's proposed law school. In part three, we examine existing TWU decisions and the extent to which they engage with and understand queer people's equality rights as framed by them. In this final part, we also address how L'Heureux-Dubé J's dissent in BCCT has informed some decisions, while other decisions have essentially ignored her blueprint for a more equal and comprehensive analysis of queer people's equality rights.

\section{QUEER THEORY AND JUDICIAL DECISIONS}

Queer theory is a relatively young branch of critical theory which emerged in the 1990s. Strongly influenced by postmodernist thought, queer theorists explored sexuality as a social construct and the product of intersecting cultural and historical circumstances. ${ }^{26}$ They sought to distinguish between the biological concept of sex, the socio-political construction of gender, and understandings of the fluidity and diversity of sexual orientations. Queer theorists emphasize that sex, gender, and sexuality are distinct but interrelated human characteristics that can change to varying degrees over time, dependent on a variety of personal and social conditions. ${ }^{27}$

The fluidity of gender and sexual expression is one of the central premises of queer theory. Accordingly, queer theorists have sought to push theories of oppression beyond the 'identity politics' of feminism or the civil rights movement. ${ }^{28}$ For queer theorists, 'queerness' is determined by the way a

23 We will discuss each of these cases in more detail below.

24 Andrews v Law Society of British Columbia, [1989] 1 SCR 143.

25 While both scholars are American and mostly discuss US law, their work can be applied to Canadian contexts.

26 Francisco Valdes, "Queering Sexual Orientation: A Call for Theory as Praxis" in Martha Albertson Fineman, Jack E Jackson \& Adam P Romero, eds, Feminist and Queer Legal Theory: Intimate Encounters, Uncomfortable Conversations, (Burlington, VT: Ashgate, 2009) at 98.

27 For more discussion about the definition of queer theory, see, Neil Cobb, “'Gay Couple's Break Like Fawlty Towers': Dangerous Representations of Lesbian and Gay Oppression in an Era of 'Progressive' Law Reform" (2009) 18:3 Soc \& Leg Stud 333 at 336.

28 Laurie Rose Kepros, "Queer Theory: Weed or Seed in the Garden of Legal Theory?" (1999-2000) 9 Law \& Sexuality 279 at 290. 
person choses to self-identify, making it an intentionally broad and inclusive concept. Any person who wants to challenge dominant understandings of sex, gender, and sexuality could consider themselves queer, regardless of whether they belonged to a sexual minority. In short, rather than focus on offering a fixed definition of queerness, queer theorists prefer to deconstruct heterosexuality and heterosexual privilege.

Though the majority of queer legal theorists are American, Canadian queer legal theorists have reached broadly similar conclusions with respect to Canadian law as their American counterparts have reached for their own law. Put simply, law has a key role to play in the production of sexual identity. ${ }^{29}$ While there have been a number of important decisions, both in Canada and elsewhere, with respect to the rights of queer people, these decisions are often lacking. ${ }^{30}$ While the queer community is no longer so overtly criminalized, ${ }^{31}$ courts generally continue to perpetuate rigid and heteronormative understandings of sex, gender, and sexual orientation. ${ }^{32}$ Much of queer legal theory focuses on addressing these deficiencies and urges legal practitioners to use queer legal theory to inform the way they engage with the practice of law. As such, queer legal theory, or at least some versions of it, can be considered more normative and less deconstructive than the queer theory which birthed it, providing roadmaps for addressing injustices against queer people and unsettling heteronormative assumptions.

For Valdes the goal of queer legal theory is the equality of queer people. ${ }^{33}$ Recognizing that equality can be elusive concept, he clarified that this struggle for equality should include efforts to promote greater queer visibility in order to dismantle the pervasive hetero-patriarchy in the legal system. ${ }^{34}$ For Valdes, the antidote to discriminatory laws (that may still be informed by heteronormative and patriarchal characteristics or assumptions), is the introduction of queer people's lived experiences into the legal system. By taking into account the lived experience and self-identified needs of queer people, laws could

29 In this regard, queer legal theory can be consistent with discourse analysis in its recognition that legal discourse is partially responsible for constructing the social world. Niemi-Kiesilainen, Honkatukia \& Ruuskanen, supra note 19 at 71.

30 See e.g. Vriend v Alberta, [1998] 1 SCR 492, 1998 CanLII 816 [Vriend]; Mv H, [1999] 2 SCR 3, 171 DLR (4th) 577. For criticisms see e.g. Lise Gotell, "Queering Law: Not by Vriend" (2002) 17:1 CJLS 89.

31 See e.g. Canada's HIV non-disclosure law, Canadian HIV/AIDS Legal Network, "Part of the Solution: A Plan of Action for Canada to Reduce HIV/AIDS-Related Stigma and Discrimination" (2005), online: <www.aidslaw.ca >; Kyle Kirkup, "Releasing Stigma: Police, Journalists, and Crimes of HIV Non-Disclosure" (2015) 46:1 Ott L Rev 127.

32 Kepros, supra note 28 at 290. For an example, see Vriend, supra note 30; Gotell, supra note 30. See also: Michael Warner, Fear of A Queer Planet, (Durham, NC: Duke University Press, 1991) at 6, "Because the logic of the sexual order is so deeply embedded by now in an indescribably wide range of social institutions, and is embedded in the most standard accounts of the world, queer struggles aim not just at toleration or equal status but at challenging those institutions and accounts. The dawning realization that themes of homophobia and heterosexism may be read in almost any document of our culture means that we are only beginning to have an idea of how widespread those institutions and accounts are." We will come back to this issue in our discussion of the TWU cases in the next section of this article.

33 Francisco Valdes, "Afterword \& Prologue: Queer Legal Theory" (1995) 83:1 Cal Law Rev 344 at 362-4 [Valdes, "Afterword"]. This is by no means agreed with by other queer legal theorists see e.g. the discussion in Aleardo Zanghellini, "Queer, Antinormativity, Counter-Normativity and Abjection" (2009) 18:1 Griffith L Rev 1 at 4-6. See also Michael Warner, The Trouble with Normal (New York: The Free Press, 1999); and Michael Warner, Publics and Counterpublics (Cambridge, MA: Zone Books 2002).

34 Valdes, "Afterword", supra note 33 at 345. 
better protect them. ${ }^{35}$ Queer legal theory is, thus, "an important voice within and without outsider jurisprudence to deconstruct ongoing, but historically-rooted subordination." "36

Valdes provides a practical roadmap for achieving queer people's equality. He lists eight methods or tactics for using queer legal theory to re-educate legal professionals and judges, and to reform existing laws and legal culture. Two of these suggested methods stand out in the context of this artilce: first, the importance of bridging social science and legal knowledge in the litigation process; and second, the importance of relying on the narratives of queer people in the litigation process in order to ensure that the queer community has a voice in the legal system. For both methods, queer visibility in legal discourses is crucial.

\section{A. Queer Visibility}

Historically, courts have reinforced the privileges of male, white, heterosexual, able-bodied, and wealthy people, and so have made the queer community and other minorities "a stranger to its laws." 37 Barrett notes that the "existence, achievements and everyday life of gay men and lesbians is largely invisible or little understood outside gay circles." ${ }^{38}$ As such, making queer people visible in the legal system, through social science evidence and the use of queer people's own narratives has significant transformative potential. Though centered on the American experience, her comments are equally applicable to Canada where knowledge of the impacts of continuing homophobia and the everyday challenges of queer people remains confined to members of the queer community. ${ }^{39}$

One threat to queer people's visibility in the legal system is what Barrett calls "pre-understanding," a term that describes how the straight majority assumes to fully understand queer people's experiences. ${ }^{40}$ Pre-understanding refers to the phenomenon of someone assuming they understand something fully while remaining blind to their own lack of knowledge, incorrect assumptions, or reliance on stereotypes. Preunderstanding effectively silences queer voices and erodes queer visibility when it takes the place of real queer experiences. Barrett argues that many well-meaning and intelligent judges can fall victim to their own pre-understanding. In the context of queer equality, for example, judges might think that marriage equality effectively eradicated homophobia in Canadian society, ${ }^{41}$ despite evidence that queer people are adversely affected personally and professionally by lingering homophobia and transphobia in Canada. Such a situation emerged in two of the TWU cases explored below. ${ }^{42}$ At the risk of speculating, it is worth noting that debates concerning marriage equality were very prominent in the public sphere in the mid2000s, and appeared to have been resolved in favour of queer people. Other issues affecting the queer

35 For example, Valdes suggests that were anti-discrimination laws drafted to reflect the fluidity of sexual identity and gender, they would better protect self-identified queers along the gender and sexual orientation spectra than they are now under more rigid definitions of homosexuality versus heterosexuality. Valdes, "Afterword", supra note 33 at 367.

36 Kepros, supra note 28 at 308.

37 Beth Barrett, "Defining Queer: Lesbian and Gay Visibility in the Courtroom" (2000) 12:1 Yale JL \& Feminism 143 at 146.

$38 \quad$ Ibid at 151.

39 Supra note 5.

40 Barrett, supra note 37 at 152. Compare this with Davina Cooper's term "limited thinkability" Davina Cooper, "Speaking beyond thinking: Citizenship, governance, and lesbian and gay politics" in Vanessa E Munro \& Carl F Stychin, eds, Sexuality and the Law: Feminist Engagements (Abington: Routledge, 2007) 171 ("Limited thinkability focuses on what is possible for local government given the political project it is pursuing and the power relations by which it is constituted. More particularly, it addresses the limits on what can be thought, understood and known" at 171).

$41 \quad N S B S$, supra note 8 at para 180; LSBC, supra note 8 at para 169.

42 See NSBS, supra note 8 at para $180 ;$ LSBC, supra note 8 at para 169 . For evidence of ongoing discrimination see sources cited in supra, notes $3 \& 5$. 
community, such as residual discrimination in the Criminal Code or discrimination in the workplace, have not figured as prominently or regularly in wider public discourses but are known and deeply felt within queer communities.

When judges write decisions that address queer people's rights and interests without any true understanding of the "historical, political, social or personal context for gay experience" their decisions can be "puzzlingly opaque"43 or, worse, reinforce hetero-patriarchal conceptions of queer people and biases in existing law. ${ }^{44}$ In order to address judicial pre-understanding, Barrett argues lawyers need to educate and guide the judiciary through the process of learning about queer theory and the lived experiences of queer people. ${ }^{45}$ As part of this process, queer people must be able to share their experiences and narratives in the courtroom to prevent them from being mischaracterized and misunderstood. Applied to the TWU context, full participation of queer parties and intervenors in these cases and judges' fulsome consideration of expert testimony by, and on behalf of, queer people is crucial.

Barrett also warns against hiding behind purely technical legal arguments in cases that engage queer people's rights and interests. Such tactics can decrease queer visibility, by ignoring the real-world impacts such decisions have on queer people's equality and wellbeing. ${ }^{46}$ In short, Barrett argues that cases involving queer people's rights should not be decided on grounds that do not include full consideration of those rights and how they could be affected by the case. Applying this principle to the TWU litigation, reducing these cases to their administrative law technicalities, and refusing to fully engage with the implications on engaged Charter rights, as was done in the $L S B C$ trial decision, ${ }^{47}$ marginalizes opportunities for educating the judiciary, risks leaving pre-understanding intact and thus results in decisions that prove harmful for queer people.

Barrett's suggested advocacy strategy for future litigators echoes and expands upon Valdes's recommendations. Both urge litigators to rely on social science and the personalized narratives of queer people as they fight to advance the visibility and equality of sexual minorities. Importantly, both assert that these strategies will lead to substantive legal change supporting sexual minorities' equality: an inclusive evidence-driven process that ensures queer visibility will tend to improve the outcome for queer people. For the purposes of this article, we would like to take this one step further and argue that this burden of introducing and understanding queer theory and queer narratives should not only rest with litigators. Rather, as we illustrate in the final two sections of this article, it is imperative for the Canadian judiciary to actively engage with queer people directly during litigation and fully and publicly consider their perspectives and evidence whenever their rights or interests are triggered in a case.

43 Barrett, supra note 37 at 149.

44 Stychin says "The categories of prohibited discrimination represent mere deviations" meaning that the norm is maintained and not unsettled. Carl F Stychin, "Essential Rights and Contested Identities: Sexual Orientation and Equality Rights Jurisprudence in Canada" (1995) 8 CJLS 49 at 52.

45 Barrett, supra note 37 at 144-5.

46 Here Barrett references Lynne Henderson, "Legality and Empathy” (1987) 85 Mich L Rev 1574 at 1576, "While there exists a tendency on the part of lawyers, judges, and - might I add - law professors, to deny a role to empathic responses in their approaches to legal problems, it is no hunch to claim that the better understanding we have of a situation at all levels, the better our decisionmaking is likely to be." Henderson also discusses how "doctrinal formality" was relied on in a death penalty trial to "make the case for death in the most lawyerly, legalistic, dispassionate form" effectively providing judges with a way to "block human pain and escape responsibility", Barrett, supra note 37 at 155.

47 This is further discussed below. 


\section{B. Queer Legal Theory in Canada}

In the past, Canadian judges have often failed to consider queer perspectives in the jurisprudence concerning the queer community. Perhaps the most egregious example of this is the Supreme Court of Canada case of Vriend, as Lise Gotell's critique makes clear. ${ }^{48}$ Vriend centred on a man, Delwin Vriend, who was fired from his job at a Christian college when he disclosed his homosexuality. The legal issue in the case was whether the failure to include protection for sexual minorities in Alberta's Human Rights legislation violated the Charter and, while the court found that it did and that the solution was to read such protection in, the decisions in the case left much to be desired. Gotell highlights the ways in which the majority's decision unwittingly reinforces the normality of heterosexuality while leaving almost no room for identities which cannot be neatly and rigidly defined as heterosexual or homosexual. ${ }^{49}$ In part, this division of rigid categories echoes the ideal of the liberal citizen as being "independent, unitary, coherent and fixed." 50 Gotell's critique centres on the identity politics of equality jurisprudence and how they result in the creation of rigid categories rather than unsettling the power dynamics which result in discriminatory treatment. ${ }^{51}$

Gotell contrasts the majority decision in Vriend with L'Heureux-Dubé J's decision in the same case. Justice L'Heureux-Dubé criticized the categorical approach because it ignored the effect of the alleged discrimination on the individual and instead focused on whether the difference in treatment was due to an analogous ground. ${ }^{52}$ Her preferred approach would have resulted in courts "examining power and disadvantage" in a way entirely absent from the majority's approach. ${ }^{53}$ Nonetheless, L'Heureux-Dubé J did not abandon the reliance on membership of a defined group which results in the same limiting of the scope of equality protections and continues to preclude any intersectional analysis under section $15 .^{54}$

Vriend may have involved a Christian college but, given the nature of the legal issue, the Court did not directly address the relationship between religious and equality rights. ${ }^{55}$ Many of the other queer rights cases in Canada have dealt with the challenges involved in the interface between religious beliefs and queer equality as those seen in the recent TWU cases. ${ }^{56}$ As Bruce MacDougall points out, such a situation highlights "the religious nature of the anti-homosexual rhetoric." ${ }^{7}$ However, the courts have sometimes sidestepped the complexity of the interaction between religious freedom and equality rights by characterizing the cases as being about something else. For example, MacDougall points out that $B C C T$ was framed as being about the capacity of the $B C C T$ to interpret education law. ${ }^{58}$ Several of the TWU decisions do something similar and we discuss this issue further in parts two and three of this article. MacDougall's comments on this tendency offer a clear echo of Barrett's concerns about courts hiding

48 Gotell, supra note 30.

49 Ibid at 91-92, 97-103.

$50 \quad$ Ibid at $97-98$.

51 Ibid at 97-104.

52 Ibid at 102 .

53 Ibid.

54 Ibid at 102-104

55 Vriend, supra note 30. The legislation was the Individual's Rights Protection Act, RSA, 1980, c H-11.7. The reason the relationship between equality rights and religious freedom was avoided had to do with the fact that the legal issue was the absence of protection for sexual minorities in the relevant legislation.

56 This is also the case internationally as well. For some examples from the United Kingdom see e.g. Carl F Stychin, "Faith in the Future: Sexuality, Religion and the Public Sphere” (2009) 29:4 Ox J Leg Stud 729; Cobb, supra note 27.

57 Bruce MacDougall, "The Separation of Church and Date: Destabilizing Traditional Religion-Based Legal Norms on Sexuality" (2003) 36:1 UBC L Rev 1 at 4 [emphasis in original].

58 Ibid at 15 . 
behind formal legal arguments rather than engaging in the implications of these cases on queer people's equality and wellbeing.

Both American and Canadian legal academics have consistently criticized the shortcomings of existing case law for queer people. ${ }^{59}$ Pre-understanding has prevented judges from being able to identify and dismantle ways in which institutionalized heteronormative thinking has denied queer people's equality. ${ }^{60}$ The absence of discussions in judicial decisions about queer people's lived experiences of discrimination and marginalization in Canadian society can reinforce the silencing of their voices in Canadian jurisprudence. ${ }^{61}$ Further, when courts fail to recognize and characterize homophobic ideas as such, because they are claimed as religious belief, they shy away from their obligations to ensure true equality between all people. ${ }^{62}$

By addressing each of these concerns as outlined by queer legal scholars, including Valdes, Barrett, Kepros, Gotell, Stychin, and MacDougall, Canadian courts can better hope to ensure justice for the queer community. Queer legal theory offers a roadmap for legal professionals and judges involved in future litigation over queer equality. This roadmap provides guidance for what must be included in the litigation process (namely education about queer history that can identify and prevent pre-understanding) and outcome (namely decisions that recognize queer people's experiences and seek to directly address their continuing marginalization in Canadian society and also Canadian jurisprudence). We now move on to examine how the decisions in $B C C T$ offer judges two paths to follow, only one of which is respectful of queer equality properly understood.

\section{LEARNING FROM THE PAST (BCCT): A MISSED OPPORTUNITY AND A BLUEPRINT FOR QUEER INCLUSION IN CANADIAN JURISPRUDENCE}

$B C C T$ centered on TWU's challenge of the British Columbia College of Teachers' $(B C C T)$ refusal to accredit its teacher training program. The $B C C T$ 's refusal was, in part, due to its concern that TWU's "Christian worldview" and its Community Standards, which prohibited "biblically condemned practices" including the "sin of homosexual behaviour," were discriminatory. Like many of the law societies in the current TWU cases, the BCCT believed accrediting the TWU program would be contrary to the public interest.

Ultimately, a majority of the Supreme Court concluded that as an administrative body charged with exercising powers delegated by the provincial government, the $B C C T$ was responsible for considering whether the TWU program was consistent with the public interest (including interests and rights specified in $\mathrm{BC}$ human rights legislation and the Charter). The majority explained that:

59 See e.g. ibid; Bruce MacDougall, "A Respectful Distance: Appellate Courts Consider Religious Motivation of Public Figures in Homosexual Equality Discourse - The Cases of Chamberlain and Trinity Western University" (2002) 35:2 UBCL Rev 511[MacDougall, "Respective Distance"]; Gotell, supra note 30. For some American examples see, Joseph J Wardenski, “A Minor Exception: The Impact of Lawrence v Texas on LGBT Youth" (2005) 95:4 J Crim L \& Crimin'y 1363; Anna K Christensen, "Equality with Exceptions? Recovering Lawrence’s Central Holding” (2014) 102 Cal L Rev 1337.

60 One example of this is the difficulty bisexual refugees have in being understood by judicial actors. Sean Rehaag, "Bisexuals Need Not Apply: A Comparative Appraisal of Refugee Law and Policy in Canada, the United States, and Australia" (2009) 13:2/3 Intl JHR 415.

61 We further examine this below in our discussion of the TWU cases.

62 MacDougall, "Respectful Distance", supra note 59 (criticizing the two cases as being about religious freedom when they are properly about queer equality). 
teachers are a medium for the transmission of values. It is obvious that the pluralistic nature of society and the extent of diversity in Canada are important elements that must be understood by future teachers because they are the fabric of the society within which teachers operate and the reason why there is a need to respect and promote minority rights. The suitability for entrance into the profession of teaching must therefore take into account all features of the education program at TWU. ${ }^{63}$

It was in this context that the $B C C T$ had an obligation to consider the discriminatory practices of TWU in its Community Standards, and how this could impact the promotion of diversity in the public-school system, and, by extension, the next generation of Canadians. ${ }^{64}$

\section{A. A Missed Opportunity: the BCCT Majority Decision}

Having established that the $B C C T$ had the jurisdiction to consider whether to accredit TWU's program with reference to the public interest, the majority then had to determine whether the $B C C T$ 's decision was correct. ${ }^{65}$ Here, the majority recognized that this case required a careful assessment of the right to equality for evangelical Christians and TWU, as well as the queer community. The majority recognized that requiring students to sign the Community Standards document created differential treatment since "a homosexual student would not be tempted to apply for admission, and could only sign the so-called student contract at a considerable personal cost" (for example, being forced to hide or deny their sexuality). ${ }^{66}$ However, the majority ultimately held that queer individuals would not be prevented from attending teacher's college elsewhere, ${ }^{67}$ insisting that the $B C C T$ needed to ensure that evangelical Christian students at TWU were able to fully access public institutions. For Justices Iacobucci and Bastarache, the $B C C T$ 's refusal to accredit TWU's program frustrated access to public institutions for evangelical Christians, but they failed to discuss how its accreditation would do the same for queer people. ${ }^{68}$ Their approach highlights the ways in which the majority decision perpetuated queer people's invisibility.

Ultimately, the majority held that because neither religious freedom nor the right to equality were absolute, a line needed to be drawn between belief and conduct. ${ }^{69}$ They explained that the freedom to hold beliefs is broader than the freedom to act on them, and that TWU students must have the right to adhere to evangelical beliefs while at TWU. This "right to adhere to beliefs" was unfortunately and, in our view, incorrectly, equated with the Community Standards document. The majority qualified their finding by noting that should any TWU graduate in the school system engage in discriminatory behaviour while acting as a teacher, the $B C C T$ would be able to step in and discipline said teacher. They found that there was no evidence to prove that training teachers at a Christian institution would necessarily make them treat queer students or colleagues unfairly or disrespectfully once in the work force and, if they did, there was a disciplinary procedure in place to address such an event. The majority thus held, "[i]n considering

63 BCCT, supra note 10 at 800 referring to its previous decision in Ross v New Brunswick School District No 15, [1996] 1 SCR 825.

64 BCCT, supra note 10 at 801.

65 Ibid at 801-805.

66 Ibid at 807.

$67 \quad$ Ibid at 814.

68 Ibid at 812.

69 Ibid at 811 . The belief-practice distinction echoes the old being-doing distinction which was once imposed on queer people, Stychin, supra note 56 at 733-734. 
the religious precepts of TWU instead of the actual impact of these beliefs on the public school environment, the $B C C T$ acted on the basis of irrelevant considerations. It therefore acted unfairly." ${ }^{\prime 70}$

The majority decision in $B C C T$ was meant to be a fair compromise between engaged rights, however, it is deeply flawed due to its failure to recognize that TWU was not simply providing an environment in which individuals could hold their religious beliefs; it was actively discriminating against an already marginalized and disadvantaged queer community. While the majority placed TWU firmly within the context of Canadian universities' constitutionally and historically protected tradition of religious affiliation, ${ }^{71}$ they failed to place TWU's accreditation controversy within the context of historical and continuing discrimination against and oppression of queer people in Canada, ${ }^{72}$ and they failed to recognize the Court's duty to uphold the Charter in a way that would provide any redress for this.

The majority's lack of context, including no discussion of the lived experiences of members of the queer community, including queer public school students, and prospective queer TWU students, faculty, and staff was not due to any lack of information before the court. In fact, the BCCT litigation included several interveners who represented the queer community. These interveners provided rich and diverse materials to assist and educate the Court in the hope of winning a progressive and ameliorative precedent to aid queer people in their struggle for equality. The majority of the court failed to engage with this material and, as a result, failed to fully address, and show that they understood, queer people's rights at stake.

Perhaps one of the more striking features of $B C C T$ is that the equality argument was raised by a Christian student and not a prospective queer student. ${ }^{73}$ Such a situation fits into the broader pattern identified by MacDougall and Short. They note that religious institutions, despite their claims of "discrimination or even persecution," are in a privileged position, particularly relative to queer people. ${ }^{74}$ To put it another way, religious institutions are fighting to maintain their privilege to discriminate while queer people are still fighting to be seen and heard. In $B C C T$, this privilege was permitted by the majority to continue, almost unchecked.

At the same time, L'Heureux-Dubé J's dissent in $B C C T$ provides a good template for future cases, providing judges with an example for how queer voices may be respected and vindicated in litigation concerning their rights. She relied on the same evidence and arguments as the majority of the court and yet her approach differed significantly from the majority's and drew on the warnings and advice of queer legal theorists.

\section{B. A Blueprint for Queer Inclusion: The BCCT Dissent}

There are three main ways in which L'Heureux-Dubé's dissent should inform future decisions as the appeals from the TWU law school cases proceed to the Supreme Court. Firstly, future judges can learn from the way in which L'Heureux-Dubé J considered the historical and contemporary social context of the $B C C T$ 's decision. Second, the extent to which she references queer interveners' arguments, extensively quotes the narratives of queer people, and attempts to understand their concerns and lived experiences sets a better standard for future judges' engagement with the queer community. Third, her dissent provides a useful template for future judges to use when acknowledging patterns of relative privilege and

\footnotetext{
BCCT, supra note 10 at 819.

Ibid at 813.

We discuss L'Heureux-Dubé J's dissent, which did a better job of this, below.

$B C C T$, supra note 10 at 854-60 (per L'Heureux-Dubé J, dissenting).

74 Bruce MacDougall \& Donn Short, "Religion-based Claims for Impinging on Queer Citizenship" (2010) 33:1 Dal LJ 133 at 136 .
} 
disadvantage in contemporary Canada and the need for courts to balance historically rooted power inequalities. In this section we discuss these three elements and suggest how they could be applied in future litigation dealing with queer equality.

\section{Historical and Contemporary Context}

In $B C C T$, L'Heureux-Dubé J spent a significant portion of her judgment discussing the experiences of queer students in the public education system. In order to do this, she examined and reflected on their unique challenges as articulated by their advocates who were interveners in that case. L'Heureux-Dubé J noted that the queer community was both ignored by and invisible to the heterosexual majority in Canadian society. She described queer students' identity as being "bumped, bruised, or completely ignored" even though it was one which "crosses all ethnic, cultural, economic, geographic, and gender boundaries." Queer students, she noted, were "universally present, yet easily invisible.""75

Such comments show sensitivity to the need for queer visibility and for institutional spaces where queer students can have their identity affirmed and accepted. Referring to social science evidence, she noted that the attitude of teachers towards sexual diversity was a "vital concern" as it could "provide validation for a gay students' self-acceptance or self-rejection."76 She also acknowledged that validation and support from the education system was of particular importance given the fact that many queer students could not rely on or expect the same kind of familial acceptance as heterosexual students. ${ }^{77}$ Justice L'Heureux-Dubé noted that because queer youth are often ostracized from their families, schools were an especially important "second line of support" in which young people can feel safe enough to explore and better understand their sexuality in healthy ways.

Not only did L'Heureux-Dubé J examine queer students' lived experiences, she also cited evidence from Health Canada that there was "an acute need for improvement in the experiences of homosexual and bisexual students in Canadian classrooms."

A self-identified gay youth, or one uncertain of his sexual identity, is bombarded by obvious and subtle messages that homosexuality is not valued. The hetero-sexual bias in educational materials and the lack of information regarding homosexuality leaves many gay youth with little support for many of their special interests and needs. This leads many youth to deny their gay identity and stay closeted at school. . . Most teachers and counsellors have a low comfort level with homosexuality and lack the skills necessary to help an adolescent who approaches with questions about homosexuality. A lack of expertise among school staff creates missed opportunities to help lesbian, bisexual and gay youth before a crisis develops. ${ }^{79}$

After considering the social science evidence put forward by interveners, L'Heureux-Dubé $\mathrm{J}$ found that, "[w]ith these statistics and observations in the foreground, the assertion that "[h]omophobia . . is one lesson students (both gay and straight) learn in the informal curriculum" is eminently plausible." ${ }^{\text {"As }}$

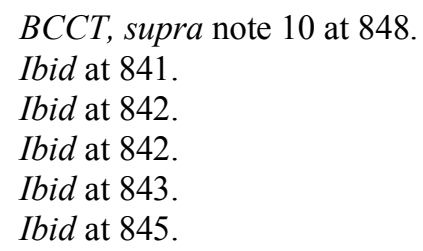


such, she found that BCCT's decision not to accredit TWU was "patently reasonable." 81 She heard, engaged with, and extensively quoted interveners' oral arguments that,

to suggest that we must await harm is to suggest that we will experiment upon children when, in fact, within our power is the power to expose the students at TWU before they enter into the public school system to that range of values that they are expected to extricate and live by while working within that public education system. ${ }^{82}$

She also recognized the fluidity and inclusivity of the queer community and allies who would be impacted by the BCCT's decision:

It is not patently unreasonable for the $B C C T$ to have denied accreditation when the audience perceiving public school teachers includes homosexual and bisexual students, parents, colleagues, and staff, students with homosexual and bisexual relatives and friends, and also adolescents exploring their sexual identities. ${ }^{83}$

Accordingly, L'Heureux-Dubé J recognized that queer people's equality is not an issue that impacts an insular or isolated community. Her inclusive approach recognized their belonging in Canadian society.

\section{Referencing Queer Interveners}

From the outset, L'Heureux-Dubé $J$ relied on the evidence of interveners to make it clear that condemnation of homosexual acts was the same as condemnation of queer people themselves.

I am dismayed that at various points in the history of this case the argument has been made that one can separate condemnation of the "sexual sin" of "homosexual behaviour" from intolerance of those with homosexual or bisexual orientations. This position alleges that one can love the sinner, but condemn the sin. But, in the words of the intervener EGALE, "[r]equiring someone not to act in accordance with their identity is harmful and cruel. It destroys the human spirit. Pressure to change their behaviour and deny their sexual identity has proved tremendously damaging to young persons seeking to come to terms with their sexual orientation"... The status/conduct or identity/practice distinction for homosexuals and bisexuals should be soundly rejected... 84

Her decision to quote EGALE, a queer advocacy group and intervener in this case, directly and at length, gave space for queer people's discussion of their own rights and experiences on their own terms. It also served to increase the visibility and understanding of who queer people are, something the majority decision failed to do. ${ }^{85}$

81 Ibid at 839.

82 Ibid at 845-6, quoting oral argument from the Ontario Secondary School Teachers' Federation.

83 Ibid at 846.

84 Ibid at 834. This approach has since been affirmed in Saskatchewan (Human Rights Commission) v Whatcott, [2013] 1 SCR 467.

85 BCCT, supra note 10 at 806-7. 
It is significant that L'Heureux-Dubé J extensively referenced the work of interveners, academics, and several government reports discussing the lived experiences of queer people. ${ }^{86}$ Her discussion concerning intervener evidence and other expert evidence not only helped her own deliberation process, it also constituted important judicial validation of the hardships experienced by members of the queer community. In a society in which queer people, their lives, history, and achievements, are largely invisible to the straight majority, making their experiences central in decisions about their equality is not only meaningful but essential to a robust vision of equality. Practically speaking, introducing queer advocates' intervener evidence and discussing it in a well-reasoned manner can also publicly demonstrate that judges heard, understood, and reflected on queer people's perspectives and narratives in their deliberations. It shows the extent to which a judge may have been educated by queer interveners, and helps to minimize any pre-understanding.

\section{Guidance on Balancing}

L'Heureux-Dubé J's dissent also provides useful guidance for future justices including Supreme Court justices who will need to examine unjust patterns of privilege and disadvantage in the intersection of conservative Christian institutions, law schools and the legal profession, and the queer community. L'Heureux-Dubé $J$ discussed at length the harm of anti-queer discrimination and the roles that the $B C C T$, teachers, and the broader education system had to play in the lives of queer students and in the public interest.

For L'Heureux-Dubé J, TWU's discrimination against queer students offered a clear parallel to racial discrimination in schools in the US. Crucially she borrowed this comparison from queer theorists ${ }^{87}$ and went on to cite to the United States Supreme Court case of Bob Jones University v United States, ${ }^{88}$ a case which saw that court deny tax-exempt status to a religious institution that prohibited interracial dating and marriage due to religious beliefs. ${ }^{89}$ For L'Heureux-Dubé J, Bob Jones University provided “an example, namely a ban on interracial dating and marriage, that is difficult to distinguish in a principled way from the ban on homosexual behaviour at issue [in the $B C C T$ case]... there can no longer be any doubt that sexual orientation discrimination in education violates deeply and widely accepted views of elementary justice." 90 By doing so, she emphasized that religious freedoms should not include the freedom to discriminate against marginalized groups. ${ }^{91}$ By drawing parallels between the more known civil rights struggle against racism in the US with the lesser-known struggle for gay rights, she also validated and made visible queer people's struggles for equality.

L'Heureux-Dubé J focused on the balancing of engaged Charter rights in her decision, rather than other formalistic legal arguments, engaging directly with the public interest and real-world implications of this rights-balancing exercise on both evangelical Christians and queer people. In addressing the reasonableness of the $B C C T$ 's decision to deny accreditation to TWU's program she recognized "there is a vital public interest in maintaining and improving supportive environments in the classrooms of our country, which are the incubators of Canada's most vulnerable and impressionable citizens." 92 When

\footnotetext{
86 Ibid at 842-48.

87 Specifically, she cites to Bruce MacDougall "Silence in the Classroom: Limits on Homosexual Expression and Visibility in Education and the Privileging of Homophobic Religious Ideology" (1998) 61 Sask L Rev 41 at 78.

88 Bob Jones University v United States, 461 US 574 (1983).

89 BCCT, supra note 10 at 835.

$90 \quad$ Ibid at 835.

91 She repeated this when assessing how the equality rights of TWU evangelical Christian students could be impacted by the BCCT's decision, ibid at 857.

92 Ibid at 820 .
} 
acknowledging that "tolerance of others" was also included in TWU's Community Standards she insisted that the public interest required more than mere toleration of the queer community. Rather, she held that public school teachers, school boards, and school administrations may have a positive duty to ensure that there is no discrimination in public schools. ${ }^{93}$ She explained that the $B C C T$ was the gatekeeper to the profession of public school teaching and that its duty to the public interest needed to be contextual and purposive. She found that signing TWU's Community Standards document made its students and employees complicit in overt acts of discrimination against queer people and that this was not simply an issue of protecting TWU students' evangelical Christian beliefs, as the majority decision had held. ${ }^{94}$ Ultimately, she found that "it is not patently unreasonable for the BCCT to treat [TWU's] public expressions of discrimination as potentially affecting the public school communities in which TWU graduates wish to teach." 95 All of these findings are also directly applicable to the current TWU appeals.

\section{Summary}

True to Valdes and Barrett's predictions, L'Heureux-Dubé J's approach to her dissent results in an outcome that is more favourable to queer people, vindicating their lived experiences, addressing their invisibility to the straight world, and using the law to rectify existing discrimination and injustice. Explicitly situating her judgment in the context of queer students' marginalization and vulnerability, L'Heureux-Dubé $\mathrm{J}$ found that the $B C C T$ 's decision not to accredit TWU was proactive and reasonable. Through her judgment, she explicitly recognized and affirmed queer (self-)identity, the inherent value of queer youth in Canadian society, and the duty of public institutions to support them as they are. While limited by the fact that this was a lone dissent, her judgment is something on which current judges should aspire to build. ${ }^{96}$ While this has arguably been done to some extent in the latest TWU v LSUC Appeal decision, the three TWU trial decisions, and two other appellate decisions fall much shorter of this mark.

\section{TWU VERSUS THE LAW SOCIETIES: THE SILENCING OF QUEER EXPERIENCE}

Between 1976 and 2011 no new law faculty opened in Canada. ${ }^{97}$ Since 2011, two new law schools have opened their doors: Thompson Rivers University Faculty of Law in 2011 and the Bora Laskin Faculty of Law at Lakehead University in 2013. Both faculties opened with relatively little or no controversy and both aimed to address the shortfall in lawyers in remote and rural communities. ${ }^{98}$ TWU submitted its proposal for a Juris Doctor program in 2012 and the Federation of Law Societies of Canada approved it in December 2013. While a majority of provincial law societies granted automatic accreditation, the Law Society of Upper Canada [LSUC] and the Nova Scotia Barristers' Society [NSBS] did not and, in June 2014, the Law Society of British Columbia [LSBC] voted to revoke their decision to accredit TWU's degree.

93 Ibid at 838 .

94 Ibid at 836.

95 Ibid.

96 Ibid at $847-8$.

97 The University of Calgary, Faculty of Law opened in 1976.

98 Tim Johnson, "Canada's newest law school” University Affairs (5 March 2012) online:

$<$ http://www.universityaffairs.ca/features/feature-article/canadas-newest-law-school/> ; Allison Jones, "Lakehead University launching new law school to ease shortage of lawyers in northern Ontario" National Post (21 August 2013) online: $<$ http://business.financialpost.com/legal-post/lakehead-university-launching-new-law-school-to-ease-shortage-oflawyers-in-northern-ontario $>$. 
In response, TWU brought separate legal challenges against each of the hold-out law societies. Each of the three trial-level decisions focused on administrative law arguments and each decision affirmed that the respective law societies are required to balance the Charter rights at stake (namely freedom of religion and queer people's equality). The courts limited themselves to focusing on assessing whether the law societies performed this balance reasonably. We discuss each trial decision in chronological order. Also, as each of the trial decisions was ultimately appealed, we end this section with a discussion of each appellate decision.

\section{A. Trinity Western University v Nova Scotia Barristers' Society 1. The Decision}

Justice Jamie Campbell of the Nova Scotia Supreme Court delivered a lengthy decision about the NSBS's refusal to accredit TWU's proposed law school. Although he asserted the case was merely about the question of whether the NSBS had the authority to do what it did, ${ }^{99}$ he spent much of his decision on the history of queer discrimination in Canada and the importance of state neutrality and secularism. The specific issue in NSBS was the Society's amended regulation about appropriate qualifications for articled clerks. Previously, articled clerks needed a JD from a faculty of common law at a Canadian university which had been approved by the Federation of Law Societies. ${ }^{100}$ Following the approval of TWU's proposed law school, the NSBS altered the regulation so that a law degree meant:

a Bachelor of Laws degree or a Juris Doctor degree from a faculty of common law at a Canadian university approved by the Federation of Law Societies of Canada for granting of such degree, unless Council, acting in the public interest, determines that the university granting the degree unlawfully discriminates in its law student admissions or enrollment policies or requirements on grounds prohibited by either or both the Charter of Rights and Freedoms or the Nova Scotia Human Rights Act. ${ }^{101}$

The amended regulation stemmed from a resolution of the NSBS council which stated that it would not approve TWU's law school unless TWU altered or offered an exemption to its Community Covenant. ${ }^{102}$ The question was: could the NSBS actually do this? Was this resolution and amendment part of "upholding and protecting the public interest in the practice of law in Nova Scotia" or was it an attempt to "regulate a law school"? ${ }^{103}$ And, if the former, had the NSBS appropriately balanced the rights at stake?

Justice Campbell found the NSBS's regulation to fall into the latter category and was thus ultra vires. While the disposition of that issue rendered the second issue - that of Charter balancing - moot, Justice Campbell opted to decide the issue regardless. However, his analysis does not deliver much balancing and proceeds in a manner more akin to a claim of a section 2(a) breach rather than the need to balance section 2(a) rights with section 15 equality rights. In fact, he does not even mention section 15 of the Charter. Campbell J ultimately found that the NSBS's regulation breached TWU's section 2(a) rights and that it was not saved under section 1 .

$99 \quad$ NSBS, supra note 8 at para 3.

100 Ibid at para 54.

101 Ibid at para 60.

102 Ibid at para 57.

103 Ibid at para 128. 


\section{The Silencing of Queer Experience: The Perils of Pre-Understanding}

To a casual reader Justice Campbell's decision appears to give a full airing to the experiences of queer people. He includes extensive references to the testimony of expert witnesses on historical and contemporary discrimination against queer people. However, an examination of the way in which he considers this evidence reveals Campbell J's pre-understanding of these issues. It is clear that even though he heard evidence of marginalization and of discrimination from a number of academics about queer experiences, Justice Campbell had already decided that queer people had achieved equality and are accepted by most people in society and thus the real issue was of religious accommodation.

In the first eleven pages of $N S B S$, Campbell J provides an overview of his decision and its rationale. ${ }^{104}$ These initial pages of his judgment, which are notable for their almost complete lack of citations or references to external sources, provide insight into his pre-understanding of the realities faced by members of the queer community. Campbell $\mathrm{J}$ actively undermines the equality rights engaged and asserts that the NSBS's decision "was not an exercise of anyone's equality rights." 105 Instead, he finds "[ $[$ ]o justify an infringement of religious liberty the NSBS action has to be directed at achieving something of significance. Refusing a TWU law degree will not address discrimination against anyone in Nova Scotia." 106 A little later in this preamble, he notes that while TWU's policy is inconsistent "with the preferred moral values of the NSBS Council....[t]he Charter is not a blueprint for moral conformity." Rather, the Charter's role was to protect the citizen from the state and not to force "citizens or private institutions [to comply] with the moral judgments of the state." 107

Not only is Justice Campbell dismissive of the impacts of this case on queer people, he also reveals a lack of sensitivity to the context of Canadian homophobia which should inform this case. In fact, he mischaracterizes both ways in which the queer community would be affected by TWU's policy and their equality rights in a paragraph which is worth reproducing in its entirety:

The NSBS has argued that it would be wrong for it to countenance or condone what counsel described as the "homophobic" policies of TWU. Many people in Nova Scotia are offended by the TWU policy. For some, particularly LGBT people, living in the knowledge that an institution with policies such as TWU's would have its degree recognized in Nova Scotia, adds to the considerable stress they already experience in their lives. There is an element of stress that is inherent in living in a multicultural society where beliefs and practices that offend majority values are not only on display, but are actively tolerated. Society does not seek to eradicate the practices or re-educate the believers but recognizes their rites and their organizations for state purposes such a solemnization of marriage, tax exemptions and charitable status. ${ }^{108}$

Further, by placing the word homophobic in quotations, he doubts and minimizes the oppression and marginalization of sexual minorities. If preventing queer people from engaging in non-heterosexual relationships is not homophobic, it is hard to imagine what is.

104 Ibid at paras 1-24.

105 Ibid at para 12.

106 Ibid 12.

107 Ibid at para 10.

108 Ibid at para 14. 
For Campbell $\mathrm{J}$, queer people are so accepted in Canadian society that to describe them as being "tolerated" makes no sense. ${ }^{109}$ Contemporary Canadian society is not, according to Campbell J, embarrassed by queer people, it is embarrassed by religious people and their "cringe-worthy" beliefs and it is these people who need our "tolerance" and "respect" for their "basic human dignity." 110 Such statements reveal that Campbell J believed he already knew enough about the queer experience in Canada and, as we now move on to show, his pre-understanding shaped his deeply dismissive approach to the evidence which described the queer experience of discrimination and inequality in Canada.

\section{Social Science Evidence in NSBS}

Justice Campbell summarized NSBS's evidence that its decision not to accredit TWU's law school "was made in the context of a troubled history of racism and discrimination" and that the NSBS had been taking steps in recent years to make the practice of law in the province more inclusive and sensitive to issues of equality. ${ }^{111}$ He spent some time in the judgment recounting the ways in which the NSBS had responded to gender equity concerns within the profession, the experiences of Indigenous Peoples within the province's justice system, and the addition of cultural competency training for legal professionals. ${ }^{112}$ Campbell $\mathrm{J}$ also noted the NSBS's commitment to enhancing access to legal services and the justice system. ${ }^{113}$

Campbell $\mathrm{J}$ delivered a lengthy summary of expert evidence introduced at trial about the history of discrimination against sexual minorities in Canada. However, he ultimately dismissed all this evidence without citing any contrary evidence introduced at trial. For example, Dr. Elise Chenier delivered expert testimony that contextualized homophobia within Canada's colonial tradition of exclusion and discrimination against Indigenous Peoples, French people, people of African descent, Chinese people, and Jewish people. Her testimony explained that these historic exclusionary ideas were supported at the time by scientific racism, and racism that was theologically supported by white Anglo-Protestants. Rather than engaging in any examination of the patterns of privilege and oppression described by Dr. Chenier, Campbell $\mathrm{J}$ instead asserted "[t]here are issues [in this theory] with which one might quibble." 114 Justice Campbell proceeded to rely on his own historical research to prove that not all Christians are responsible for white Anglo-Protestant privilege in Canada, ${ }^{115}$ thus refusing to take the opportunity to redress any of the power differentials that were brought to his attention in the expert testimony.

For Campbell J, Dr. Chenier's testimony, or as he put it "[h]er opinion," had "some highly informative historical analysis" but "[i]nformative does not necessarily translate into relevant for the purposes of resolving this case." 116 The problem for Campbell J was that Dr Chenier's testimony failed to conclusively establish "whether the actions by the NSBS will reduce the amount of that discrimination or ameliorate its effects." 117 Yet, upon examination of her testimony as reported by Campbell J, she arguably did do this, explaining that

\footnotetext{
Ibid at para 22.

Ibid at paras 23-24.

Ibid at para 62.

Ibid at paras 62-80.

Ibid at paras 78-80.

Ibid at para 83.

Ibid at footnote to para 83.

Ibid at para 82.

Ibid 82.
} 
based on decades of historical research it is clear that a policy that prohibits people who engage in same-sex sexual activity from membership, employment or participation has two principal effects on gays and lesbians. They will either be deterred from seeking employment, membership or participation or they will pursue the opportunity and hide their sexual orientation. In both instances the individual is harmed; in the first, by exclusion and lost opportunity and in the second by being forced to hide a part of oneself, through limited disclosure and various concealment strategies. Both cause considerable stress with adverse psychological, health and job-related outcomes. ${ }^{118}$

She further explained that "[b]y legitimizing acts of discrimination, it sends a clear signal to its citizens that discrimination is acceptable and justifiable, and will be defended." 119 While Justice Campbell accepted her historical evidence, he described her findings on the effects of legitimizing discrimination as a "value statement" he disagreed with. ${ }^{120}$

Though he dismissed part of Dr. Chenier's testimony because of a lack of evidence, he expressly agreed with another part even though he noted it lacked "empirical... support." ${ }^{21}$ That part was her comment that it is only a minority of modern Christians "who oppose homosexuality and equality for lesbians and gays." 122 Here Campbell J seems to be implying that the real oppressed minority are those like the students of TWU. His comments here are bookended by references to "exclusionary policies" and the shifting nature of Christian ideology in response to "the worldview of those in power." 123 There is much in these parts of Dr. Chenier's testimony that would be problematic in a strict religious freedom sense but Campbell J's decision to quote them seems designed to discredit her while also suggesting that her position supports his own: that it is groups like TWU, and not queer people, who are oppressed or at risk of oppression. ${ }^{124}$

Following his discussion of Dr. Chenier's evidence, Campbell J examined Dr. Mary Bryson's evidence about gender and sexuality in the context of education. Dr. Bryson's testimony supported the conclusions that sexual minorities would be effectively excluded from TWU's law school due to its Community Covenant, and that there was considerable historical and contemporary social science evidence that this exclusion would perpetuate and exacerbate already existing stigmatization and marginalization of the queer community. Dr. Bryson noted that "[t]here can really be little question that LGB students exposed to an environment of discrimination suffer long term and very significant negative outcomes in education, health and others areas of life." ${ }^{125}$ Although Dr. Bryson's testimony seems to corroborate that of Dr. Chenier, as with Dr. Chenier's evidence, Campbell J remained unconvinced.

Campbell $\mathrm{J}$ refers directly to an excerpt in Dr. Bryson's affidavit in which she connects TWU discrimination to the broader context of already existing homophobia in contemporary Canadian society:

\footnotetext{
118 Ibid at para 90.

119 Ibid at para 91.

120 Ibid at para 99.

121 Ibid at para 97.

122 Ibid.

123 Ibid at paras 96, 98.

124 This is certainly an argument to be mindful of going forward and it is not our goal for religious individuals to face the same pressure to keep themselves private and hidden as was and is faced by queer people; rather, our point is that judges ought not to be dismissive of the queer experience. For more on the argument about not pushing religious people into the same predicament as queer people, Stychin, supra note 56 at 733.

125 See e.g. NSBS, supra note 8 at para 106.
} 
[t]he fact that the Nova Scotia Barrister's [sic] Society, as an institutional body has voted to refuse to provide accreditation to Trinity Western University Law School, knowing full well of the existence of a discriminatory Community Covenant, appropriately and productively anticipates the need to address fairly and proactively the recruitment of sexual minorities into the legal profession and importantly, represents a constructive refusal to add to, or to condone, the deleterious impacts of minority stress already experienced by LGB people in the larger community. ${ }^{126}$

However, Campbell $\mathrm{J}$ finds this to be a legal conclusion without any supporting legal argument arguably not a responsibility expert witnesses are required to shoulder. Again, Justice Campbell dismissed this testimony, asserting it was not relevant to his consideration of the more narrow issue of law student "recruitment." 127 Without much rationale or any supporting trial evidence to the contrary, Campbell J dismissed Bryson's expert evidence of the harmful impact of TWU's discrimination against queer people.

As noted, Justice Campbell was especially concerned with religious freedom. As he put it " $[\mathrm{t}] \mathrm{he}$ discomforting truth is that religions with views that many Canadians find incomprehensible or offensive abound in a liberal and multicultural society. The law protects them and must carve out a place not only where they can exist but flourish." "28 That may be so, but the question must again become what about equality? Campbell $\mathrm{J}$ barely mentions equality rights in his decision and clearly doubts how they may be engaged and what is at stake for queer people in this case.

Justice Campbell did find that "[f]or many or most LGBT people the experience of attending such a place [TWU] would be traumatic and potentially damaging." ${ }^{29}$ Furthermore,

[i]t is very clear that there are systemic and widespread effects of regulatory authorities' permitting or approving discrimination in institutional settings. Where discrimination is allowed to take place there are of course damaging effects. It is also not surprising that LGBT people suffer when they live in states where they are made to feel unvalued by the formal refusal to recognize equality rights through same-sex marriage. ${ }^{130}$

However, he immediately followed these observations with the assertion that "[n]one of that has application here." "131 Campbell J even went so far as to characterize the NSBS' actions as being about the public perception of the legal profession, suggesting that the NSBS wanted to be seen as doing the 'right' thing rather than engaging with whether or not they were doing the right thing. ${ }^{132}$ According to Campbell $\mathrm{J}$, the NSBS had fallen victim to popular opinion rather than respecting religious freedom. For Justice Campbell, the NSBS' position was 'in effect a statement of principle to stand in solidarity with LGBT people" which "has no connection to the equality rights of the LGBT community or the public interest in the practice of law in Nova Scotia. That's less a statement about equality than a statement about the futility of just making statements." 133 This belief led him to find that, "[t]he value of the statement of principle

126 Ibid at para 120.

127 Ibid at para 121.

128 Ibid at para 271.

129 Ibid at para 251.

130 Ibid at para 252.

131 Ibid at para 253.

132 Ibid at para 255.

133 Ibid at para 16. 
made by refusing to recognize TWU law degrees is not proportional to the direct and substantial impact on freedom of religion." ${ }^{134} \mathrm{He}$ asserted,

The outrage, sense of emotional pain, minority stress or hurt feelings that some Nova Scotians experience from knowing that a person trained at a university in British Columbia that does not recognize same-sex marriage can still potentially become a lawyer in Nova Scotia, does not change the fact that what the NSBS is purporting to regulate is university policy. ${ }^{135}$

\section{B. Trinity Western University $v$ The Law Society of Upper Canada \\ 1. The Decision}

In April, 2014, the Benchers of the LSUC voted against accrediting TWU. Much as was the case in $N S B S$, TWU challenged this decision on the grounds that it was "unauthorized and otherwise invalid."136 TWU argued that the LSUC was only allowed to determine whether its law school would "graduate competent lawyers" and that "it was not open to the respondent to consider broader public interests in reaching its decision." 137 On this point the three-member panel of the Ontario Superior Court disagreed and found that the LSUC was entitled to consider "a much broader spectrum of considerations with respect to the public interest when they are exercising their functions, duties and powers, including whether or not to accredit a law school."138

The Court also disagreed that the $B C C T$ decision was determinative of the case, finding that it differed factually, legally, and in terms of the question posed. ${ }^{139}$ The Court noted that unlike the Community Standards document at issue in $B C C T$, the Covenant was required and a failure to sign and abide by it would be damaging to the student's future at TWU. The Court also pointed out that there are a limited number of places at Canadian law schools, with about three applicants for every seat in a first-year class. ${ }^{140}$ Nonetheless, the court agreed that the LSUC's decision did infringe section 2(a) of the Charter. ${ }^{141}$ LSUC is more explicit about the need to balance Charter rights than NSBS. The court found that the Benchers' speeches displayed an awareness that they needed to balance competing rights and subtly chastised TWU's assertion that their religious freedom was ignored. ${ }^{142}$

The court found the LSUC's balancing to be reasonable and so TWU's application for judicial review was dismissed. In contrast to $N S B S$ where it was the law society who was attempting to extend its reach, in $L S U C$, it was TWU. The court characterized TWU's actions as trying to use freedom of religion to compel LSUC to act. ${ }^{143}$

Ibid at para 18.

Ibid at para 180.

LSUC, supra note 8 at para 1.

Ibid at paras 53, 54.

Ibid at para 58.

Ibid at paras 59-60.

$40 \quad$ Ibid at para 67.

141 Ibid at para 91.

142 Ibid at para 103

143 Ibid at para 120. 


\section{The Silencing: The Right Decision But the Wrong Reasons}

$L S U C$ continued certain aspects of the silencing seen in NSBS. Queer people are mentioned explicitly only a handful of times in the decision while the religious equality argument is analyzed in detail. ${ }^{144}$ The court also preferred to engage with discussions about generic equality rather than the need for queer people's equality more specifically.

The court recognized the LSUC's assertion that "the principles of equity and diversity have been at the heart of its governance of the legal profession for more than two hundred years of its existence." 145 It cited several historical moments over the course of this period in which the LSUC tried to ensure greater access of marginalized communities (namely Roman Catholics, visible minorities, and women) to the practice of law. ${ }^{146}$ The court found that the LSUC, in carrying out its delegated powers under the Law Society Act, was required to maintain and advance the cause of justice and rule of law, facilitate access to justice, and meet its duty to protect the public interest. ${ }^{147}$ As such, it agreed that the LSUC had the jurisdiction to consider broad issues of public interest when determining whether to accredit TWU's proposed law school.

Interestingly, the court also held that the LSUC was entitled to consider the significance of publicly giving recognition and approval to TWU's institutionalized discrimination against certain minorities, noting, "[c]ondoning discrimination can be ever much as harmful as the act of discrimination itself." 148 By doing so, the court recognized the importance of government institutions, bound by the Charter, publicly speaking out against discrimination in contemporary Canadian society. There are some ways in which the courts' decision in this case does the same.

In determining whether the majority decision in $B C C T$ should govern their decision (and by extension require it to grant TWU's appeal), the court explained that human rights law is dynamic and constantly evolving. ${ }^{149}$ Moreover, the court noted that in the fifteen years since $B C C T$, attitudes towards queer people had changed "considerably." 150 Accordingly, "[s]ome of the presumptions or predispositions that may have existed in the past, and which may have informed decisions at that time, cannot now be safely relied upon." 151

From the perspective of those advocating for queer people's equality, it is significant that the court recognized its obligation to take into account the contemporary reality for queer people. Recognizing such an obligation is, however, not the same as carefully fulfilling it. The court noted that for queer people to attend TWU would require them to "sign a document in which they agree to essentially bury a crucial component of their very identity, by forsaking any form of intimacy with those persons with whom they wish to form a relationship." 152 TWU argued that such a situation would not "intrude on the rights of LGBTQ persons" but the court disagreed, noting that "it is accepted that sexual conduct is an integral part of a person's very identity. One cannot be divorced from the other." ${ }^{153}$

\footnotetext{
144 References to queer people can be found in ibid at paras 13,15, 70, 104, 111,113, 116, 133. Most of these references are in passing only and not about queer people's lived experiences.

145 Ibid at para 21.

146 Ibid at paras 22-24.

147 Ibid at para 28.

148 Ibid at para 116.

149 Ibid at para 70.

150 Ibid.

151 Ibid.

$152 \mathrm{Ibid}$ at para 113.

153 Ibid at para 13.
} 
Insofar as $L S U C$ explores the equality rights of queer people in more detail, it does so on more abstract and generic grounds. The court uses the language of "equal access" and "equal opportunity" without really engaging with the unique challenges or lived experiences of queer people. There are vague references to equal access being in the public interest but nothing specific to queer people or the value of the diversity of experiences and worldviews that queer people can bring into the legal profession.

In subsuming queer equality into a generic equality and failing to adequately situate the appeal within a context of continuing homophobia in Canadian society, $L S U C$ unwittingly perpetuates queer people's invisibility. Such efforts are common with respect to minority groups and can be characterized as the "I don't see X, I just see people" argument. These arguments function as a silencing and denial because they cannot see the ways in which queer people are shaped by their queerness and the discrimination they continue to face for it. It renders anti-queer discrimination as something beyond the court's imagination and therefore something the court does not have to address or take responsibility for.

That being said, before moving on to our discussion of $L S B C$, it is worth briefly outlining the ways in which $L S U C$ spoke out against some of the problematic findings in NSBS. First, it disapproved of Justice Campbell's finding that the NSBS's action was not directed at preventing discrimination in the province. Here, the Court noted that it was more likely that both the LSUC and the NSBS were acting in good faith when they refused to accredit TWU due to its discriminatory Covenant. ${ }^{154}$

Second, the Court also challenged Justice Campbell's de minimis approach to analyzing the discriminatory effects of TWU's covenant, insisting that discrimination is discrimination no matter how many people it could apply to:

Discrimination is not evaluated on a numbers basis. It should be self-evident that, since discrimination is usually directed at minorities, the number of people who experience the effect of discrimination will be fewer in number than the people who are the source of the discrimination. Discriminatory actions are no less discriminatory because they only effect a few rather than many. ${ }^{155}$

Such comments speak to the power of courts to express support for, or condemn, certain ways of thinking that can be harmful to the development of progressive jurisprudence.

\section{Trinity Western University v The Law Society of British Columbia 1. The Decision}

The Law Society of British Columbia's [LSBC] route to court with TWU was more winding than that of the LSUC or NSBS. Just prior to TWU receiving approval from the Federation of Law Societies, LSBC amended its rules for admittance so that it would have the option to approve a law faculty's accreditation separately from the Federation's approval. In short, approval by the Federation no longer automatically, or always, resulted in that faculty's JD being sufficient for admittance to LSBC. ${ }^{156}$ In April 2014, the LSBC's Benchers voted to defeat a motion that would have revoked TWU's approval. Some of the LSBC's members then requested a special general meeting which would consider a resolution directing Benchers to declare that TWU's law school was not an approved faculty. At the special meeting, the resolution passed which lead to a further meeting of the Benchers who opted to hold a referendum of all of the LSBC's members about the resolution. The referendum also supported the resolution and in October

154 Ibid at paras 131-132.

155 Ibid at para 134.

156 LSBC, supra note 8 at paras $31-33$. 
2014 the Benchers voted to implement the resolution and withdraw approval from TWU. Consequently this led to BC's Minister for Advanced Education withdrawing his approval also. ${ }^{157} \mathrm{TWU}$ then challenged the LSBC's decision on the grounds that it was ultra vires and an unjustifiable infringement of their Charter rights. ${ }^{158}$

One notable difference in $L S B C$ is that the BC Supreme Court followed a correctness standard rather than the reasonableness standard used in the other cases. ${ }^{159}$ Chief Justice Hinkson found that the Benchers had "wrongfully fettered their discretion" by following the outcome of the referendum, instead of following their own judgment. ${ }^{160}$ As a result the Benchers had also failed to perform an appropriate balancing of Charter rights in their second decision on the matter. ${ }^{161}$ All of which meant the Benchers' decision to revoke approval could not stand. Chief Justice Hinkson's remedy was to reinstate the earlier decision which approved TWU's law school given that that decision did balance Charter rights. ${ }^{162}$

\section{Silencing Queer Voices via Their Interventions}

Several groups sought intervener status in the proceedings. Eleven organizations who supported TWU were granted intervener status in proceedings: the Attorney General of Canada, The Association For Reformed Political Action-Canada, Canadian Council of Christian Charities, Christian Legal Fellowship, Evangelical Fellowship of Canada, Christian Higher Education Canada, Justice Centre For Constitutional Freedoms, The Roman Catholic Archdiocese of Vancouver, The Catholic Civil Rights League, The Faith and Freedom Alliance, and the Seventh-Day Adventist Church in Canada. Of these, four were permitted to submit oral arguments: the Attorney General of Canada and three faith groups. Five organizations that supported LSBC were granted intervener status: West Coast Women's Legal Education and Action Fund, Outlaws UBC, Outlaws UVIC, Outlaws TRU and Qmunity. Of these organizations, only West Coast LEAF was permitted to submit oral arguments. Of the three stakeholder groups in this decision (Christians, women, and the queer community), only those representing the queer community were excluded from addressing the Court in person. As such, this is perhaps the most overt example of silencing in the TWU trilogy, and speaks directly to the failure of this case to realize its educative and reform potential. Without fully including the queer community in the judicial process, it is no wonder that the decision falls short of ensuring justice for queer people.

The $L S B C$ decision also fails to undertake any analysis of the social or historical context from which the case arises, further eroding queer visibility in this case. In fact, Hinkson CJ, is careful to engage only with the technical administrative law issues at play in this case, ultimately confining his role to distilling the narrow administrative law findings in $B C C T$ and applying them to the new facts in this case.

Further, Chief Justice Hinkson initially adopted the over-generalized characterization of the Charter rights at stake from the $L S U C$ decision. He found that the religious freedom of TWU and its evangelical Christian students was engaged, as were the "rights of both current and future members of the [LSBC] to equal access, on a merit basis, to membership that the [LSBC] had a duty to protect." ${ }^{163}$ While evangelical Christians' rights were explicitly identified and recognized, the equality rights engaged in this case were not initially explicitly connected to the queer community. Only much later on in the decision did Hinkson CJ note, in just one sentence, that the case included an argument that TWU's Covenant was "contrary to

157 Ibid at paras 37-49.

158 Ibid at para 51.

159 Ibid at paras 79-101.

160 Ibid at para 120.

161 Ibid at para 151.

162 Ibid at paras 151, 156.

163 Ibid at para 139. 
the equality rights of its future members, who include members from two historically disadvantaged minorities (LGBTQ persons and women), and was thus discriminatory." 164 However, Chief Justice Hinkson refused to provide any analysis or discussion of the substance of these rights, instead noting that nothing in the evidentiary record convinced him that the LSBC adequately considered these competing interests, leaving it "unnecessary" for him to "resolve the issue of the collision of the relevant Charter rights." 165

Such a brief, cursory commentary can in no way be considered a meaningful discussion of ongoing homophobia and transphobia in Canada, or of queer people's right to equality. The fact that no queer interveners were permitted to address the court directly, and the fact that Hinkson CJ refused to engage with any substantive discussion of the queer community's Charter rights engaged in the case, prevent $L S B C$ from properly acknowledging, let alone addressing the rights of queer people.

\section{TWU Appeal Decisions}

In 2016, appeals for all three cases were heard in their respective provinces, and in all three cases, the appellate courts affirmed the decisions of their respective lower courts. Again, we discuss each case in chronological order, starting with the decision in the LSUC Appeal and ending with the decision in $L S B C$ Appeal.

\section{Building on L'Heureux-Dubé J's blueprint: The LSUC Appeal}

TWU sought to appeal the Divisional Court's ruling that the LSUC decision not to accredit was reasonable. The university argued the LSUC's decision was ultra-vires, as it should have limited its deliberations to whether future TWU graduates would make competent lawyers. Despite TWU's arguments, the Court of Appeal focused most of its decision on the Charter grounds for the LSUC's decision, and affirmed the lower court's finding that the LSUC's consideration of engaged Charter rights was fair and reasonable.

From the start of its decision, the Court of Appeal recognized that TWU's Community Covenant discriminated against the queer community. ${ }^{166}$ The court also correctly characterized the equality rights of queer people in this case, namely equal access to a limited number of law school seats, and thus queer people's access to the legal profession. The court distinguished this from any arguments that the Covenant could increase the likelihood of future TWU graduates to behave in discriminatory ways within the legal profession, thus differentiating the case from the $B C C T$ decision. ${ }^{167}$

The court's approach to this case echoed several aspects of Justice L'Heureux-Dubé's dissent in BCCT. It demonstrated a significant amount of sensitivity in its attempts to understand and convey the queer community's concerns. When engaging in their review of the rights-balancing efforts undertaken by the LSUC, the court recognized queer students could only sign the Covenant and attend TWU at "considerable personal cost."168 The court then affirmed the lower court's finding in LSUC that the Covenant did not just discourage same-sex relationships, it actively excluded queer individuals from the university, as sexual conduct could not be legally separated from one's sexual orientation. ${ }^{169}$ Significantly, the court also relied on direct quotations from queer intervenors, Out on Bay Street and OUTlaws, who stressed,

164 Ibid at para 143.

165 Ibid at para 153.

166 LSUC Appeal, supra note 9 at para 6.

167 Ibid at para 58.

168 Ibid at para 116.

169 Ibid at para 117. 
"The Covenant is not merely an expression of TWU's beliefs. The Covenant is a document that discriminates against LGBTQ persons by forcing them to renounce their dignity and self-respect in order to obtain an education" and "LGBTQ persons applying to TWU, or who come out while at TWU, will experience the stigma of not belonging and other destructive effects of regulating queer sexuality." 170

MacPherson JA, writing for the court, addressed this testimony directly, noting,

I agree with, and adopt, these statements by the Supreme Court of Canada, the Divisional Court, and the intervenors Out on Bay Street and OUTlaws. My conclusion is a simple one: the part of TWU's Community Covenant in issue in this appeal is deeply discriminatory to the LGBTQ community, and it hurts."

This is an important recognition by the court of how queer people would experience the Covenant and how it would impact their rights to equality in very real ways.

Not only did the court build on L'Heureux-Dubé J's dissent in BCCT by prominently featuring queer intervenors in its decision, it also drew from L'Heureux-Dubé J's discussion of the US case, Bob Jones University. The court explained that like Bob Jones University, TWU was applying to access a public benefit (the accreditation of its law school), and the LSUC had a right to deny this in the public interest due to the institution's discriminatory Covenant. ${ }^{172}$

In its discussion about the public interest mandate of the LSUC, the court referenced an excerpt from a well-known speech by then Chief Justice Dickson. In this excerpt, the former Chief Justice underscored the importance of those involved in the law school admissions processes to ensure equal access to law school seats, and actively encourage people from minority groups to join the profession. ${ }^{173}$ Implicit in this discussion by the court, is the recognition of the historical disadvantage of the queer community and the need to redress this by ensuring their equal access to the profession.

\section{Avoiding the Charter at All Costs: The NSBS Appeal}

The NSBS appealed Justice Campbell's trial decision to the Nova Scotia Court of Appeal. On appeal it argued, amongst other things, that Justice Campbell's decision should be reversed since it failed to consider any of the Charter implications of the NSBS accreditation decision, and that Justice Campbell erred in his decision by not addressing section 15 concerns in even a cursory way. ${ }^{174}$ However, the Court of Appeal refused to discuss either of these issues, instead limiting its analysis to formalistic legal arguments concerning administrative law. When the NSBS's factum, quoted at length in the decision, provided several arguments in favour of a broad interpretation of their duty to regulate the legal profession in the public interest, the court refused to engage with the argument at all, finding it too abstract to be useful $^{175}$ - a stark example of the kind of narrow legal scoping Barrett and MacDougall warned against.

The appellate court ultimately affirmed the trial decision, finding that the Legal Professions Act could not authorize the NSBS to issue rulings on whether a person or institution in BC violated the Human Rights Act or the Charter. The court held that as a private university, the Charter did not apply to TWU. Further, it found the amended NSBS regulation preventing accreditation of the TWU law school to be ultra-vires.

170 Ibid at para 118.

171 Ibid at para 119.

172 Ibid at paras 136-8.

173 Ibid at para 131.

174 NSBS Appeal, supra note 9 at para 35.

175 Ibid at paras 100-1. 
As we discussed earlier, the $N S B S$ trial decision was one of the more problematic of the original TWU trilogy of cases. It exhibited the starkest examples of judicial pre-understanding of the queer community, as well as the most troubling dismissal of expert social science evidence concerning historical and contemporary infringements on queer people's equality rights. In light of these concerns, it is disappointing that the Court of Appeal refused to engage with any Charter issues in its judgment. The opportunity for some redress for queer people's historical and continuing discrimination was lost as a result. This legal precedent ultimately frustrates future judicial efforts to recognize queer people's equality, silences queer voices in Canadian jurisprudence, and reinforces their institutional marginalization moving forward.

\section{Affirming Pre-Understanding: The LSBC Appeal}

The $L S B C$ Appeal decision potentially sets back queer equality even further than its trial decision did, echoing many of the more worrying aspects of the NSBS trial decision. The British Columbia Court of Appeal mischaracterizes the equality rights of queer people; it displays the same types of preunderstanding seen in $N S B S$ resulting in the same identification of the queer community as the more privileged party compared to TWU; and it summarily dismisses expert testimony concerning homophobia in Canada without citing any contrary evidence to support such findings.

On appeal, the LSBC introduced evidence which attested to the harm caused by TWU's Covenant on the queer community. In his expert testimony, Dr. Barry Adam discussed the detrimental effects of not publicly affirming queer people's relationships, and situated these effects within the context of a persistent and widespread lack of social and familial support for queer people. In summarizing his evidence, the court noted that Dr. Adam provided an "extensive record of social science investigation [that] any implementation or enforcement of a policy of exclusion reproduces the conditions that lead to well demonstrated deleterious consequences for lesbian, gay and bisexual people." 176 Another expert, Dr. Ellen Falkner, also spoke to specific detrimental effects of the TWU's Covenant on queer students. She observed that due to the limited number of law school seats in Canada, queer students may feel they have to apply to TWU's law school and sign the Covenant at a significant cost. She noted that having to do so could push queer people "back into the closet," that it would require them to "[live] a lie in order to obtain a degree," or engage in self-censorship of relationships otherwise sanctioned and protected by Canadian law. She concluded that it could further isolate queer individuals and re-pathologize homosexual identity, denying the harm of homophobia. ${ }^{177}$

However, in the face of all this expert testimony, the court asserted that while these detrimental effects could be significant, they were not assured to happen. In fact, the court only referred to them as "potential effects," and immediately made reference to the fact that there were queer students who had signed TWU's Covenant, ${ }^{178}$ implicitly assuming those students had not experienced any hardship in doing so. While the LSBC argued that queer people's equality rights had to be protected by ensuring equal access to the limited number of law school seats in Canada, the court failed to accept that TWU's Covenant posed any hindrance to such equal access. It asserted that it was "incontrovertible that refusing to accredit TWU would not enhance accessibility." "I79 Instead the court noted that the number of seats open to queer students with or without TWU accreditation would not change and that they could effectively ignore the existence

\footnotetext{
176 LSBC Appeal, supra note 9 at para 109.

177 Ibid at para 110.

178 Ibid at para 171.

179 Ibid at para 175.
} 
of the school. ${ }^{180}$ Such logic is deeply flawed as it fails to address the fact that the percentage of law school spots available for queer students would be lower than that for straight students.

In characterizing how TWU's Covenant could infringe queer people's equality, the court dismissed all expert testimony, relying solely on its pre-understanding of the current experiences of the queer community. Rather than accepting the extensive expert evidence about the history of exclusion and marginalization of the queer community, the court asserted that the queer community could not possibly constitute an "oppressed minority" since the "majority of Canadians," according to the court, "supported marriage rights" of queer people. ${ }^{181}$ Echoing NSBS, the court conceded that while the Covenant could be "offensive and hurtful" to queer people, such feelings of discomfort are unavoidable in free and democratic societies. It also stressed that this issue should not be considered too seriously as it considered the TWU Covenant to be more benign than hate speech. ${ }^{182}$ The court continued:

Indeed, it was evident in the case before us that the language of "offense and hurt" is not helpful in balancing competing rights. The beliefs expressed by some Benchers and members of the Law Society that the evangelical Christian community's view of marriage is "abhorrent," "archaic" and "hypocritical" would no doubt be deeply offensive and hurtful to members of that community. ${ }^{183}$

The court actively downplayed the significance of the Covenant, noting that even were it not to exist, queer students would not likely be attracted to TWU due to its "culture", asserting rather defensively in the next paragraph that the court's belief was "not cynical." 184 This fails to acknowledge the difference in consequences for queer students should they wish to attend TWU: with the Covenant, they could be expelled should their sexual orientation be discovered and reported, endangering their education - to say nothing of the harm which would flow from a public body accrediting an explicitly discriminatory program.

Interestingly, when engaging with arguments concerning the LSBC's duty to protect the public interest, the court held that a decision to accredit TWU's law school would facilitate the plurality of views which is important in a democracy, and that such a decision would not necessarily condone the contents of the Covenant. ${ }^{185}$

All of this deliberation led the court to ultimately find that while the Covenant could "in principle" have a detrimental effect of the queer community and their right to equality, this would be "insignificant in real terms". ${ }^{186}$ When the court compared it to the effects of the lack of LSBC accreditation on TWU, it found that this would effectively prevent the school from opening, which it determined to be immediately "detrimental and severe." 187 While the court refused to recognize that any infringement of queer people's equality rights would result from the LSBC's accreditation of TWU's proposed law school, it ultimately found that LSBC's refusal to accredit the school "unreasonably infringed" TWU's religious rights. ${ }^{188}$

\footnotetext{
180 Ibid at para 174.

181 Ibid at para 178.

182 Ibid at para 188.

183 Ibid at para 189.

184 Ibid at para 176-7.

185 Ibid at paras 181-89

186 Ibid at para 179.

187 Ibid at para 168.

188 Ibid at para 192.
} 


\section{CONCLUSION}

In their judicial review of the NSBS's, LSUC's, and LSBC's decisions not to accredit TWU's proposed law school on the grounds of the public interest and queer people's equality, Canadian courts had an opportunity to examine and redress historic and persistent marginalization of queer people within the legal system (including within the legal profession). These courts had the duty to advance the equality of queer people. They also had an opportunity to provide judicial recognition of persisting homophobia in contemporary Canadian society. However, all decisions, except for LSUC Appeal, ultimately failed to adequately realize the educative and reform potential of each case and, in their own way, silenced and perpetuated the marginalization of queer voices and invisibility of queer people.

We encourage future judges to ensure their decisions do not reinforce their own pre-understanding of the queer community or the societal discrimination against, or marginalization of queer people. Established jurisprudence is clear that substantive equality under section 15 of the Charter requires judges to take into account the claimants' experience of the alleged discrimination. This ultimately requires empathy from judges and it will likely involve a process in which judges are educated about the claimant groups' lived experiences of discrimination. It will also likely require some self-reflection on the part of judges, perhaps acknowledging their own relative privilege, the persisting heteronormative biases in the legal system, and their accompanying duty not to perpetuate unjust patterns of privilege and disadvantage.

As these cases, except for NSBS, are pursued to the Supreme Court, we encourage future judges to assess how these recent decisions differ from L'Heureux-Dubé J's dissenting judgment in $B C C T$. It is important that the failures of the NSBS, $L S U C$, and $L S B C$ cases not set back equality jurisprudence for the queer community in Canada. By following the example provided by Justice L'Heureux-Dubé, and applied in the LSUC Appeal, future judges can also increase queer people's visibility in the legal system and thus better protect their equality within and outside of the legal profession.

Drawing on queer legal theorists' work, and L'Heureux-Dubé's BCCT dissent, we offer two suggestions for a comprehensive and equitable approach to deciding similar cases in the future. Firstly, such cases should not be decided purely on formalistic administrative law grounds: these cases will impact important Charter rights, and these rights must be fully examined and balanced. Secondly, in any efforts to balance religious rights and queer people's equality rights, lawyers and courts must make sure queer people are visible throughout the deliberative process and in ultimate decisions. This necessarily requires the following three principles: firstly, courts must be careful to ensure they are correctly characterizing queer people's equality rights. In the current TWU litigation, the equality rights engaged for queer people concern equal access to law school seats, and by extension the legal profession. These rights must be understood within the context of the need for diversity within the legal profession, as recognized by several Canadian law societies. Second, Courts must recognize and condemn the persistent and pervasive homophobia and transphobia in Canadian society. For example, any future TWU litigation should take into account the way in which the university and its Covenant will impact queer people's wellbeing as well as their ongoing struggle for equality. Thirdly, judges should actively engage with evidence provided by queer people concerning their current lived experiences of marginalization in Canada, as well as how acts like accrediting TWU's law school would affect their equality rights and wellbeing. This necessarily requires the full participation of queer claimants and intervenors throughout the litigation process. It also requires judges to accept queer people's evidence, unless they can point to specific and defensible evidence to the contrary (as opposed to their own assumptions).

The blueprint for more equitable decisions is there, it just needs to be applied and affirmed as binding case law. 